logos_i_ethos_2020_(52), s.135-149

DOI: http://dx.doi.org/10.15633/lie.3581

Marek Wójtowicz

ORCID 0000-0001-5759-2113

Uniwersytet Śląski w Katowicach

\title{
Idea cybernieśmiertelności a struktura bytu ludzkiego
}

Transhumanizm stał się obecnie jednym $\mathrm{z}$ najczęściej podejmowanych tematów badań humanistycznych i społecznych. Chociaż w dużej mierze odwołuje się do wiedzy przyrodniczej i perspektyw rozwoju technologicznego, to formułuje śmiałe tezy o charakterze antropologicznym, takie jak: radykalna ewolucja gatunku ludzkiego, nadejście Osobliwości czy technoanulaMarek Wójtowicz - dr hab., prof. UŚ, filozof, zatrudniony na Wydziale Teologicznym Uniwersytetu Śląskiego w Katowicach, członek Instytutu Filozofii UŚ. Autor książek Doświadczenie lęku egzystencjalnego jako sytuacja wyboru, Katowice 2005 oraz Zakład Pascala - argumentacja i działanie, Katowice 2016; współredaktor (z W. Kanią) pracy zbiorowej Filozofia a śmierć, Katowice 2007; autor ponad 30 artykułów naukowych. Zainteresowania naukowe: filozofia religii, antropologia filozoficzna, psychologia religii.

cja śmierci. Bez wątpienia wymagają one pogłębionej refleksji, która mogłaby ujawnić ich właściwe znaczenie i ewentualne następstwa. Szczególnie potrzebne są - jak się wydaje - dociekania filozoficzne. Trzeba krytycznie przeanalizować same podstawy koncepcji, które już wkrótce mogą stać się inspiracją dla konkretnych działań technicznych i społeczno-politycznych. Błędem byłby brak odniesienia się filozofów, w tym zwłaszcza etyków, do zjawisk, które - trudno rozstrzygnąć, czy słusznie - budzą określone niepokoje i wątpliwości.

Przedmiotem analiz zawartych w niniejszym tekście będzie idea cybernieśmiertelności - jedna $\mathrm{z}$ najistotniejszych, nowatorskich treści koncepcji transhumanistycznych. Idea ta zostanie najpierw możliwie wiernie przedstawiona, a następnie poddana analizie głównie pod 
względem obecnych w niej założeń filozoficznych dotyczących struktury bytu ludzkiego. Jest to zamiar zasadny, gdyż twierdzenia transhumanistów zwykle pozbawione są bezpośrednich odniesień do zakładanych przez nich najogólniejszych poglądów na świat, człowieka czy społeczeństwo.

\section{Transhumanistyczne perspektywy wydłużenia ludzkiego życia}

Transhumaniści głoszą konieczność radykalnego przeobrażenia życia człowieka. Nawiązują przy tym do paradygmatu ewolucyjnego, ale zarazem nadają mu nowy kształt. Ray Kurzweil przedstawia sześć faz ewoluującej rzeczywistości; obecnie według niego jesteśmy u progu piątej epoki, która: „pozwoli nam przezwyciężyć odwieczne ludzkie problemy i znacznie wzmocni ludzką kreatywność. Zachowamy i ulepszymy inteligencję, którą obdarzyła nas natura, pokonując jednocześnie głębokie ograniczenia ewolucji biologicznej”' ${ }^{1}$. Czekające nas zmiany nabiorą innego niż w przeszłości charakteru. Ludzkość wreszcie stanie się zarazem przedmiotem i podmiotem ewolucji - sama będzie kontrolować kierunek oraz przebieg doskonalenia się Homo sapiens. Wyrażają to określenia używane przez transhumanistów: „świadoma ewolucja”, „ewolucja projektanta” czy „rewolucja udoskonalenia”. Przyszła postać człowieka ma w sobie zawierać nieporównanie większe niż dotychczas możliwości: rozwoju intelektualnego, samorealizacji, osiągania szczęścia. Transhumaniści są przekonani, że dokona się to za sprawą postępu technologicznego.

Jedną z wymiernych korzyści ukierunkowanej ewolucji człowieka ma być przedłużenie jego życia. Realizację tego celu transhumaniści upatrują w dwóch zasadniczych rodzajach działań. Pierwszym z nich jest inżynieria genetyczna, powszechnie stosowana już do optymalizowania

1 R. Kurzweil, Nadchodzi osobliwość: kiedy człowiek przekroczy granice biologii, tłum. E. M. Chodkowska, A. Nowosielska, Warszawa 2013, s. 34.

${ }^{2}$ H. Tirosh-Samuelson, J. B. Hurlbut, Introduction: Technology, Utopianism and Eschatology, w: Perfecting Human Futures: Transhuman Visions and Technological Imaginations, eds. J. B. Hurlbut, H. Tirosh-Samuelson, Wiesbaden 2016, s. 7, doi: 10.1007/978-3-658-11044-4. 
uprawy roślin i hodowli zwierząt. Nietrudno wyobrazić sobie ingerowanie w genotyp człowieka, choć budzi to wiele wątpliwości o charakterze etycznym ${ }^{3}$. Drugim, bardziej akcentowanym działaniem wydłużającym ludzkie życie jest cyborgizacja, która - rozumiana w aspekcie medycznym - polega na wykorzystywaniu zdobyczy techniki do doskonalenia zdrowia człowieka. Proces ten dokonuje się już od wielu lat, a za przykład mogą posłużyć wszczepiane w ludzkie ciało implanty ślimakowe i stomatologiczne, rozruszniki serca czy endoprotezy stawu biodrowego. Transhumaniści są przekonani, że wkrótce powszechne staną się syntetyczne organy uzyskiwane za pomocą biodrukarek $3 \mathrm{D}$ i wyposażone w mikrochipy, które będą stale monitorować stan organizmu, a w razie nagłej potrzeby wezwą pogotowie ratunkowe ${ }^{4}$.

Należy podkreślić, że planowanego przedłużenia ludzkiego życia nie można porównywać do korzystnych zmian, jakie zaobserwowano w krajach najwyżej rozwiniętych w drugiej połowie XX wieku. Takie czynniki, jak upowszechnienie standardów higieny, skuteczna walka ze skażeniami wody i powietrza czy podniesienie poziomu i dostępności świadczeń medycznych pozwoliły podwyższyć średni wiek życia ich obywateli o kilka/kilkanaście lat. Pod tym względem transhumaniści okazują się rewolucjonistami - nie wahają się zapowiadać zmian radykalnych. Aubrey de Grey na początku XXI wieku zapowiedział, że średnia długość życia osób urodzonych w roku 2100 przekroczy 5000 lat $^{5}$, a niedawno zapewnił, że już urodził się człowiek, który przeżyje tysiąc lat ${ }^{6}$. W obszarze medycyny ma się dokonać, w oparciu o najnowsze zdobycze techniki, niewiarygodny postęp.

Jeśli te optymistyczne prognozy są wiarygodne, to wyjątkowo dramatyczna wydaje się sytuacja obecnego pokolenia, a co najmniej znacznej

3 Por. M. Klichowski, Narodziny cyborgizacji: nowa eugenika, transhumanizm i zmierzch edukacji, Poznań 2014, s. 72-82.

4 Por. J. Łepkowski, Transhumanizm - nowa religia? [dokument elektroniczny], (2018), s. 112114, doi: 10.13140/RG.2.2.22307.55840.

5 Por. A. de Grey, The War on Aging, w: The Scientific Conquest of Death: Essays on Infinite Lifespans, Buenos Aires 2004, s. 38.

${ }^{6}$ Por. J. Łepkowski, Transhumanizm - nowa religia?..., dz. cyt., s. 16. 
jego części. Otóż współcześnie żyjący ludzie mogą nie doczekać urzeczywistnienia się procedur medycznych gwarantujących wymarzoną długowieczność albo też, co prawdopodobnie byłoby jeszcze trudniejsze do przyjęcia, dostępność do owych procedur może okazać się ograniczona. Jak pogodzić się z koniecznością śmierci w wieku ledwie kilkudziesięciu lat, gdy niemal „na wyciągnięcie ręki”, w perspektywie kilku czy kilkunastu lat normą stanie się przeżycie wielu wieków, a może i tysiącleci?

Rozwiązaniem tej kwestii proponowanym przez transhumanistów jest krionika. Wyspecjalizowane kliniki oferują możliwość głębokiego zamrożenia ( $w$ ciekłym azocie, $w$ temperaturze $-196^{\circ} \mathrm{C}$ ) ciała zmarłej osoby. Od pewnego czasu istnieje także opcja zamrożenia jedynie głowy bądź mózgu. Po wniesieniu stosownej opłaty (od kilkunastu tysięcy dolarów wzwyż) można z nadzieją oczekiwać, że w przyszłości specjaliści będą potrafili wpierw wyleczyć zaistniałą przyczynę śmierci, wobec której obecna medycyna jest bezradna, a następnie przywrócić życie zachowanym w możliwie jak najlepszym stanie „,szczątkom doczesnym”. Kilka takich klinik funkcjonuje już w Stanach Zjednoczonych, jedna w Rosji; przechowują one ciała (części ciał) kilkuset osób. Warto dodać, że do tej pory nauka nie wypracowała żadnej metody, która chociażby przybliżała możliwość przywrócenia do życia, „zmartwychwstania” zamrożonego ciała $^{7}$.

\section{Transfer umysłu}

Inżynieria genetyczna oraz cyborgizacja ludzkiego ciała nie są wcale ostatecznymi środkami transhumanistycznej ewolucji człowieka. Jej zwieńczeniem nie ma być udoskonalony przez technologiczne osiągnięcia Homo sapiens, lecz w zasadzie nowy, wykraczający poza wszelkie biologiczne ograniczenia gatunek: postczłowiek. Często prognozowany rozwój osoby opisywany jest przez sekwencję trzech pojęć:

7 Por. M. Klichowski, Narodziny cyborgizacji..., dz. cyt., s. 136-138; J. Łepkowski, Transhumanizm - nowa religia?..., dz. cyt., s. 13-15. 
człowiek - transczłowiek - postczłowiek. Dopiero ta ostatnia postać ma być optymalna, zawierać w sobie całkowite samourzeczywistnienie potencjału ludzkiego. „Postczłowiek osiągnie stan intelektualny niewyobrażalnie przekraczający stan intelektualny znanych nam geniuszy, będzie absolutnie odporny na wszelkie choroby, pełen wigoru i zawsze młody, posiądzie zdolność pełnej kontroli nad wszystkimi swoimi procesami psychicznymi, nigdy nie dopadnie go zmęczenie, znużenie czy rozdrażnienie, a także osiągnie permanentne szczęście, pełnię miłości, spokoju oraz stany świadomości nam całkowicie niedostępne"8. Postczłowiekowi przypisuje się też nieśmiertelność.

W tym miejscu warto przedstawić zasadniczą różnicę między długowiecznością a nieśmiertelnością. Mogłoby się wydawać, że doprowadzenie średniej długości życia człowieka do poziomu wspomnianych kilku tysięcy lat mocno zbliża ludzkość do osiągnięcia gwarancji życia bez końca. Tak jednak nie jest. Długowieczność transczłowieka, nawet potencjalnie wciąż (aż do nieskończoności) przedłużana, nie uchroni go przed ryzykiem utraty życia. Jeśli nawet udałoby się wyeliminować najpowszechniejsze obecnie przyczyny zgonów (nowotwory oraz choroby układu sercowo-naczyniowego), skutecznie leczyć wszystkie przewlekłe choroby oraz powstrzymać starzenie się organizmu, to i tak pozostaje problem nagłej śmierci, na przykład w wyniku wypadku czy morderstwa ${ }^{9}$. Zawsze umierali także w pełni zdrowi ludzie i trudno wyobrazić sobie stan rzeczywistości, w której do tego nie dochodziłoby.

Proponowaną przez zwolenników transhumanizmu drogą do nieśmiertelności ma się stać transfer umysłu (mind uploading). Polega on na wyodrębnieniu treści umysłowych osoby w taki sposób, aby możliwe stało się ich przeniesienie poza układ nerwowy, w konsekwencji zrywając zależność człowieka od jego kruchej i nietrwałej warstwy biologicznej. Jak się wydaje, powodzenie tego przedsięwzięcia przyniosłoby dwie zasadnicze korzyści. Po pierwsze, struktury mózgowe przestałby

8 M. Klichowski, Narodziny cyborgizacji..., dz. cyt., s. 112.

9 Por. I. Ziemiński, Życie wieczne: przyczynek do eschatologii filozoficznej, Poznań-Kraków 2013, s. 133. 
ograniczać rozwój naszego umysłu, który wreszcie mógłby przyswoić wiele zdobyczy współczesnej techniki dedykowanych do tej pory wyłącznie komputerom ${ }^{10}$. Po drugie, co jest kluczowe dla prowadzonych tu rozważań, transfer umysłu ma zapewnić człowiekowi pełną kontrolę nad swoim życiem i śmiercią.

Objaśniając swoją wizję nieśmiertelności, transhumaniści zwykle sięgają do analogii komputerowych. „W języku informatyki można by powiedzieć, że transfer umysłu odpowiada przetłumaczeniu niezrozumiałego kodu źródłowego (umysłu) na zrozumiały język, a następnie uruchomieniu go w nowym, komputerowym środowisku" ${ }^{11}$. Człowiek porównywany jest do „pliku umysłu” albo „software'u”, który daje się „zeskanować” (wyodrębnić) oraz „przesłać” z jednego „nośnika” czy „hardware'u” (na przykład ciała/mózgu) na inny. W cyfrowo ujmowanego człowieka można coś „wgrać” lub „zainstalować”, można go „formatować" $i$, aktualizować”. Wydaje się, że przynajmniej niektórzy transhumaniści wcale nie traktują tych pojęć metaforycznie, jakby byli pewni, że przeznaczeniem ludzkiej rzeczywistości jest jej pełna cyfryzacja. Tak czy inaczej, tego rodzaju perspektywę nieskończonego wydłużenia życia człowieka nazywa się zwykle cybernieśmiertelnością albo technoanulacją śmierci.

$\mathrm{W}$ tym miejscu warto przedstawić niektóre $\mathrm{z}$ wysuwanych wobec tej idei wątpliwości. Najpierw należy rozważyć, jaki charakter ma przedłużone istnienie obiecywane $\mathrm{w}$ ramach cybernieśmiertelności. O nieśmiertelności mówi się także w kontekście sławy, wybitnych dzieł artystycznych czy genów przekazywanych kolejnym pokoleniom. W takich przypadkach życie wieczne nie jest rozumiane dosłownie. Transhumaniści zapowiadają możliwość rzeczywistej nieśmiertelności osoby, chociaż różni się ona od najczęstszych jej wyobrażeń, zazwyczaj formułowanych na gruncie religii. Życie wieczne w raju dokonuje się w warunkach rzeczywistości nadprzyrodzonej, jest pod każdym względem doskonałe,

10 Por. R. Kurzweil, Jak stworzyć umyst: sekrety ludzkich myśli ujawnione, tłum. Z. Zielińska, Białystok 2018, s. 255-263.

11 J. Łepkowski, Transhumanizm - nowa religia?..., dz. cyt., s. 106. 
gdyż gwarantuje to doskonałość Boga. Z kolei cybernieśmiertelność ma się ziścić $\mathrm{w}$ doczesności, a co za tym idzie, będzie wiązać się z pewnymi zagrożeniami. Funkcjonowanie cyfrowe wymaga stałego dopływu energii, który może zostać $\mathrm{z}$ różnych powodów przerwany, a ponadto zinformatyzowane treści narażone są na zniszczenie przez szkodliwe oprogramowanie (wirusy, konie trojańskie). Istnieją oczywiście i będą doskonalone systemy zabezpieczeń o wysokim stopniu niezawodności (programy antywirusowe, tworzenie kopii zapasowych), ale na przykład ogólnoświatowy krach energetyczny mógłby skutkować śmiercią przekształconego cyfrowo człowieka.

Innym dyskutowanym zagadnieniem jest związek cybernieśmiertelności z realizacją najgłębszych ludzkich pragnień, ze szczęściem. Transhumaniści posługują się pojęciem ekstropia (extropy), które - w przeciwieństwie do procesu entropii, czyli zmniejszania się uporządkowania układu termodynamicznego - oznacza nieustanny, spontaniczny progres człowieka. Max More, twórca Extropy Institute, przewiduje, że „ludzie będą mogli żyć o wiele dłużej w zdrowiu lepszym niż doskonałe, wzbogacać samowiedzę i świadomość procesów interpersonalnych, uwalniać się od kulturowych, psychologicznych i memetycznych uprzedzeń w myśleniu, ulepszać inteligencję we wszystkich jej formach i uczyć się, jak zmieniać się i wzrastać. W skrócie: ludzie ostatecznie będą szczęśliwi”12. Cybernieśmiertelność nie jest celem samym w sobie, lecz środkiem umożliwiającym realizację ekstropii. Za wartość naczelną uważana jest wolność jednostki, której ważnymi przejawami powinny stać się zarówno ochrona przed „niedobrowolną” śmiercią, jak i uniknięcie przymusowej nieśmiertelności przez podjęcie decyzji o zakończeniu cyfrowej egzystencji ${ }^{13}$. Zapewne jednak najbardziej fundamentalne jest rozstrzygnięcie kwestii, czy cybernieśmiertelnemu bytowi wciąż przysługiwałoby miano istoty ludzkiej. Czy postczłowiek nie byłby raczej maszyną?

12 H. Tirosh-Samuelson, Facing the Challenges of Transhumanism: Philosophical, Religious, and Ethical Considerations, http://transhumanism.asu.edu/pdf/2007_news_challenges.pdf(11.12.2019).

13 Por. D. Misztal, Religijne aspekty transhumanizmu, w: Granice sacrum: wymiary religijności w myśli współczesnej, red. T. Sieczkowski, P. Grabarczyk, Łódź 2017, s. 140; J. Łepkowski, Transhumanizm - nowa religia?..., dz. cyt., s. 16. 
Kontrolowany przez człowieka proces ewoluowania samego siebie do stanu cybernieśmiertelności musiałby się wiązać z niezwykle znaczącymi zmianami jego statusu ontycznego. Synonimem osoby ludzkiej przestałoby być pojęcie „śmiertelnik”. Czy zatem i inne określenia, zazwyczaj używane do opisu bytu ludzkiego, takie jak: przygodność, złożoność czy zmienność, również uległyby dezaktualizacji? Co stanowiłoby warunek ciągłości ludzkiej tożsamości? Ta seria pytań bez wątpienia domaga się gruntownego rozważenia. W dalszej części tekstu refleksja ograniczona zostanie tylko do jednej grupy problemów - do dylematów związanych ze strukturą bytu ludzkiego.

\section{Nowa postać materializmu}

Wśród zagadnień antropologii filozoficznej wyróżnia się - tak przypisywanym jej znaczeniem, jak i rozległością możliwych teoretycznych ujęć - problematyka bytowej struktury człowieka. Już od starożytności filozofowie starali się przedstawić spójny obraz osoby ludzkiej, który trafnie opisałby daną w wewnętrznym doświadczeniu jedność, a zarazem i złożoność jej natury. Sformułowano i stosownie uargumentowano rozmaite koncepcje, najczęściej o charakterze monistycznym (sprowadzającym byt ludzki do jednego wymiaru) albo dualistycznym (uznającym współistnienie dwóch części składowych, najczęściej duszy i ciała), albo też podkreślającym jedność zróżnicowanego wewnętrznie człowieka. W obliczu perspektywy cybernieśmiertelności konieczne jest ponowne przemyślenie dotychczas przyjmowanych rozstrzygnięć.

Najbardziej istotne modyfikacje towarzyszące ewolucji człowieka zdają się dotyczyć jego ciała. „Będziemy żyć w sieci, tworząc projekcje ciał, gdy tylko będziemy ich potrzebować, $\mathrm{w}$ tym także ciał wizualnych w najróżniejszych królestwach rzeczywistości wirtualnej, ciał holograficznych, ciał tworzonych w oparciu o foglety, a także ciał fizycznych, obejmujących roje nanorobotów i innych form nanotechnologii” ${ }^{14}$. Więk-

14 R. Kurzweil, Nadchodzi osobliwość..., dz. cyt., s. 319. 
szość transhumanistów głosi nieuchronność nadejścia epoki postbiologicznej. Człowiekowi, utożsamianemu $\mathrm{z}$,umysłem postbiologicznym”, nie będzie już potrzebna sfera cielesna, a ponieważ generuje ona trudne do przezwyciężenia problemy, więc zostanie od niej całkowicie uwolniony ${ }^{15}$. Ciało miałoby się okazać sferą nienależącą do istotnego wyposażenia natury ludzkiej.

W tradycji filozoficznej nie raz formułowano stanowiska, które odrzucały warstwę biologiczną jako konieczny element istoty człowieka. Zwykle przyjmowały one postać spirytualizmu albo, szerzej, panpsychizmu. Koncepcje transhumanistów mają zupełnie inny charakter. Ich rozumienie człowieka opiera się na traktowaniu psychiki wyłącznie w kategoriach procesów fizycznych, które możemy poznawać za pomocą metod przyrodoznawstwa, interpretowanych w zgodzie $\mathrm{z}$ tezami materializmu ${ }^{16}$. Wizja bezcielesnego postczłowieka nie oznacza odseparowania jego bytu od materialnego podłoża, ale przetransformowanie owego podłoża w formę doskonalszą. Biologiczne ciało - które obecnie może być traktowane jedynie jako interface między umysłem a doświadczeniem $^{17}$ - ma zostać zastąpione o wiele bardziej niezawodnym, chociaż zarazem niespersonalizowanym nośnikiem danych: pendriveem, dyskiem komputera, chmurą internetową.

Czy istotę pozbawioną własnego ciała można nadal nazywać człowiekiem? Na to pytanie zwykle odpowiadano negatywnie ${ }^{18}$. Jako jeden $\mathrm{z}$ ważnych argumentów za tym rozstrzygnięciem przytacza się konieczność zmysłowego doświadczania rzeczywistości, bez którego nie są możliwe ani poznanie, ani samoświadomość ${ }^{19}$. Transhumaniści, odpierając ten zarzut, rysują perspektywę funkcjonowania umysłu w rzeczywistości

15 Por. M. Klichowski, Narodziny cyborgizacji..., dz. cyt., s. 126-127.

16 Por. D. Misztal, Religijne aspekty transhumanizmu..., dz. cyt., s. 139.

17 Por. H. Tirosh-Samuelson, Transhumanism as a Secularist Faith, „Zygon” 47 (2012) no. 4, s. 713, doi: 10.1111/j.1467-9744.2012.01288.x.

18 Nawet wyraźnie dualistyczne koncepcje religijne, przypisujące człowiekowi mało istotne, śmiertelne ciało oraz nieśmiertelną duszę przedstawiają życie po śmierci jako istnienie ucieleśnione.

19 To na przykład pogląd Emmanuela Lévinasa, por. J. Słomka, Zagadnienie cielesności w ujęciu Emmanuela Lévinasa: rozkosz erotyczna i pieszczota..., „Logos i Ethos” $2020 \mathrm{nr}$ 52, s. 115-118. 
wirtualnej umożliwiającej odbiór informacji o charakterze percepcyjnym. Wiadomo przecież, że najbardziej nawet różnorodne bodźce zmysłowe przetwarzane są w receptorach na impuls nerwowy dostarczany do mózgu. Postęp techniczny powinien umożliwić bezpośrednie przekazywanie informacji postrzeżeniowych do postbiologicznego umysłu. Są zresztą także plany połączenia takiego umysłu ze sztucznym ciałem, które zachowałoby i dodatkowo rozszerzyło możliwości percepcyjne ciała biologicznego ${ }^{20}$.

Istotę bytu ludzkiego transhumaniści sprowadzają do umysłu, którego funkcjonowanie uwarunkowane jest jednak związkiem $\mathrm{z}$ takim czy innym materialnym podłożem. Czym jednak jest umysł i czy nie należy utożsamiać go $\mathrm{z}$ duszą? Zdecydowanie nie. Koncepcja transhumanistów tylko pozornie przypomina kartezjański dualizm, w którym nośnik danych (biologiczny bądź niebiologiczny) byłby odpowiednikiem ciała, a umysł - duszy ${ }^{21}$. Faktycznie umysł ludzki rozumiany jest zgodnie $\mathrm{z}$ tezami funkcjonalizmu obliczeniowego (maszynowego): stanowi on wyłącznie byt materialny, zaś świadomość ma charakter informacyjny i działa na podobieństwo komputera. Umysł ,jest programem komputerowym, ciągiem operacji wykonywanych przez odpowiednią maszynę liczącą. «Umysł to zjawisko z poziomu software względem mózgu, który odgrywa rolę hardware»" 22 .

Transhumanistyczna koncepcja człowieka okazuje się jednowymiarowa. Fenomen ludzkiego bytu w całości sprowadzony zostaje do materii ujmowanej w ściśle stechnicyzowany sposób. Trudno takiego stanowiska nie określić mianem redukcjonizmu: „Z jednej strony bowiem ujmują one [idee transhumanistów - M. W.] człowieka jako pewien całościowy rezultat procesu ewolucyjnego, jednak $\mathrm{z}$ drugiej - rozwijając wizję jego przyszłości, niejako wypreparowują z tej całości jeden wyróżniony

20 Por. J. Łepkowski, Transhumanizm - nowa religia?..., dz. cyt., s. 106-107.

21 Por. M. Klichowski, Narodziny cyborgizacji..., dz. cyt., s. 136.

${ }^{22}$ M. Klinowski, Funkcjonalizm obliczeniowy - kilka uwag z perspektywy ewolucyjnej, „Rocznik Kognitywistyczny" 2 (2008), s. 38. 
komponent, redukując człowieczeństwo właśnie do niego. Zastępują cielesno-mentalną złożoność informatyczną prostotą" ${ }^{23}$.

Takie ujęcie istoty człowieczeństwa generuje swoiste dylematy. Jerzy Łepkowski wyszczególnia tylko niektóre z nich: „jak wygląda kwestia świadomości wirtualnej osoby? Czy skopiowany umysł jest tym samym umysłem, czy umysłem nowym, ale posiadającym pamięć poprzedniego? W jakim stopniu przetransferowany umysł jest tożsamy z człowiekiem, który jest (a raczej był) jego właścicielem? Co dzieje się z człowiekiem, który nie umiera w procesie transferu umysłu? Który byt jest rzeczywiście nim i jaki łączy ich stosunek? Jak wygląda relacja uploadu ze światem cyfrowym, a jak z materialnym?"24. Zadaniem niemal niewykonalnym jest nie tyle udzielenie odpowiedzi, ile nawet jednoznaczne zidentyfikowanie znaczenia tak sformułowanych pytań.

Warto zaznaczyć, że transhumaniści najczęściej wprost nie ujawniają arbitralnie przyjętych założeń antropologicznych. Być może obawiają się, że osłabiłoby to głoszone przez nich idee, prezentowane zazwyczaj w duchu obiektywizmu, bezzałożeniowości i pełnej zgodności z wynikami badań naukowych. Mało tego, niektórzy przedstawiciele omawianego nurtu usiłują, w mało przekonujący sposób, wpisać swoje poglądy w klasyczny, psychofizyczny obraz natury ludzkiej. Dowodzą, że oczekiwana ewolucja człowieka będzie miała także charakter autentycznego duchowego przebudzenia, gdyż dopiero uwolnienie się od biologicznych ograniczeń ujawni boskie pierwiastki tkwiące w naszym umyśle $e^{25}$.

Mogłoby się wydawać, że w odniesieniu do kwestii istnienia/nieistnienia rzeczywistości nadprzyrodzonej zwolennicy cybernieśmiertelności, z jej materializmem i redukcjonizmem, będą skłonni opowiadać się za ateizmem albo jakąś formą religii naturalnej. Jednakże współcześnie istnieją liczne organizacje i stowarzyszenia o charakterze religijno-transhumanistycznym. Ich członkowie zwykle nie podejmują intelektualnej

23 D. Misztal, Religijne aspekty transhumanizmu..., dz. cyt., s. 151.

24 J. Łepkowski, Transhumanizm - nowa religia?..., dz. cyt., s. 108.

25 Por. J. Łepkowski, Transhumanizm - nowa religia?..., dz. cyt., s. 110-111. 
refleksji nad kierunkami rozwoju technologicznego, ale tworzą wspólnoty, których członków łączy afirmacja wybranych tez dotyczących kontrolowanej ewolucji człowieka oraz najrozmaitszych idei religijnych i quasi-religijnych ${ }^{26}$.

\section{Uwagi końcowe}

Narzuca się pytanie o możliwość nieodległego spełnienia się transhumanistycznych wizji, w tym idei cybernieśmiertelności. Wbrew optymistycznym opiniom ich zwolenników nadal należy je zaliczać - jak się wydaje - raczej do kategorii science fiction niż do realnych perspektyw wynikających z postępu technologicznego. Przejście od aktualnych osiągnięć z zakresu robotyki czy nanotechnologii do transferu umysłu jest wciąż niewyobrażalne.

Funkcjonalizm obliczeniowy, leżący u podstaw koncepcji technoanulacji śmierci, $z$ trudem wytrzymuje stawiane mu zarzuty. Mają one zwykle charakter kognitywistycznych wywodów (na przykład argument chińskiego pokoju, za pomocą którego John Searle przekonuje o braku możliwości zastąpienia ludzkiego umysłu przez imitujący go program komputerowy) albo wykazują sprzeczność redukcjonistycznego rozumienia ludzkiej psychiki z dotychczasową wiedzą o naturze procesów ewolucyjnych. Niewątpliwe sukcesy w rozwoju komputeryzacji i badań nad sztuczną inteligencją nie dają dostatecznych podstaw do traktowania umysłu wyłącznie jako mechanizmu ${ }^{27}$.

Przed wiarą $\mathrm{w}$ transhumanistyczne obietnice przestrzegają także psychologowie ewolucyjni. Podkreślają oni nasz nadal niewielki zasób wiedzy na temat adaptowania się ludzkiego mózgu do wyzwań środowiska. W dużej mierze nie rozumiemy racji, dla których pewne zmiany w obrębie naszej psychiczności okazały się w przebiegu historii Homo sapiens pożyteczne i się zachowały, inne zaś - zanikły. „Interwencja człowieka

26 Por. J. Łepkowski, Transhumanizm - nowa religia?..., dz. cyt., s. 74-81.

27 Por. M. Klinowski, Funkcjonalizm obliczeniowy..., dz. cyt., s. 39-43. 
w proces ewolucyjny może wydać ludzi o ponadludzkiej inteligencji, ale nie wiemy, jakie będą niezamierzone konsekwencje takiej interwencji"28. Przeprowadzona analiza dotknęła jednego z ważnych aspektów stanowiska transhumanistów. Ograniczenie się przy tym niemal wyłącznie do zbadania idei cybernieśmiertelności okazało się uzasadnione, gdyż zabieg ten pozwolił ujawnić antropologiczne założenia nie tylko tej konkretnej idei, ale i szerszej wizji rozumienia człowieka w transhumanizmie. Mało przekonywająca materialistyczna i funkcjonalistyczna koncepcja ludzkiego bytu każe nader krytycznie spoglądać na ufundowane na niej śmiałe tezy dotyczące naszej przyszłości.

\section{Bibliografia}

Grey A. de, The War on Aging, w: The Scientific Conquest of Death: Essays on Infinite Lifespans, Buenos Aires 2004, s. 29-45.

Klichowski M., Narodziny cyborgizacji: nowa eugenika, transhumanizm i zmierzch edukacji, Poznań 2014.

Klinowski M., Funkcjonalizm obliczeniowy - kilka uwag z perspektywy ewolucyjnej, „Rocznik Kognitywistyczny” 2 (2008), s. 37-44.

Kurzweil R., Jak stworzyć umyst: sekrety ludzkich myśli ujawnione, tłum. Z. Zielińska, Białystok 2018.

Kurzweil R., Nadchodzi osobliwość: kiedy człowiek przekroczy granice biologii, tłum. E. M. Chodkowska, A. Nowosielska, Warszawa 2013.

Łepkowski J., Transhumanizm - nowa religia? [dokument elektroniczny], (2018), doi: 10.13140/RG.2.2.22307.55840.

Misztal D., Religijne aspekty transhumanizmu, w: Granice sacrum: wymiary religijności w myśli wspótczesnej, red. T. Sieczkowski, P. Grabarczyk, Łódź 2017, s. 135-156.

Słomka J., Zagadnienie cielesności w ujęciu Emmanuela Lévinasa: rozkosz erotyczna i pieszczota, „Logos i Ethos” 2020 nr 52, s. 107-119.

Tirosh-Samuelson H., Facing the Challenges of Transhumanism: Philosophical, Religious, and Ethical Considerations, http://transhumanism.asu.edu/pdf/2007_news_challenges.pdf (11.12.2019).

${ }^{28}$ H. Tirosh-Samuelson, Facing the Challenges of Transhumanism..., dz. cyt. 
Tirosh-Samuelson H., Transhumanism as a Secularist Faith, „Zygon” 47 (2012) no. 4, s. 710-734, doi: 10.1111/j.1467-9744.2012.01288.x.

Tirosh-Samuelson H., Hurlbut J. B., Introduction: Technology, Utopianism and Eschatology, w: Perfecting Human Futures: Transhuman Visions and Technological Imaginations, eds. J. B. Hurlbut, H. TiroshSamuelson, Wiesbaden 2016, s. 1-32, doi: 10.1007/9783-658-11044-4.

Ziemiński I., Życie wieczne: przyczynek do eschatologii filozoficznej, Poznań-Kraków 2013.

\section{Abstrakt}

\section{Idea cybernieśmiertelności a struktura bytu ludzkiego}

Jedną z najważniejszych idei transhumanizmu jest zamiar radykalnego przedłużenia ludzkiego życia, a ostatecznym celem - całkowite pokonanie śmierci. Ma się to dokonać za sprawą transferu umysłu, a więc przeniesienia całego wyposażenia jednostki w wymiar cyfrowy. Postczłowiekowi, niezależnemu od biologicznego ciała, będzie wówczas przysługiwać możliwość cybernieśmiertelności. Perspektywa ta budzi wiele wątpliwości. $\mathrm{W}$ artykule przedstawiona jest analiza filozoficznych podstaw transhumanistycznego immortalizmu. Okazuje się, że bazuje on na jednym ze współczesnych wariantów materializmu: funkcjonalizmie obliczeniowym - problematycznej, redukcjonistycznej koncepcji kognitywistycznej.

\section{Słowa kluczowe}

transhumanizm, cybernieśmiertelność, struktura bytu ludzkiego, funkcjonalizm obliczeniowy

\section{Abstract \\ The Conception of Cyber-immortality and the Structure of Human Being}

One of the most important ideas of transhumanism is an intention to radically prolong human life, and the ultimate goal - to defeat death completely. This is to be done 
by the mind uploading, and thus transferring all the equipment of a person into a digital dimension. The posthuman, independent of the biological body, will then be entitled to the possibility of cyber-immortality. This prospect raises a lot of doubts. The article presents an analysis of the philosophical foundations of transhumanist immortalism. It turns out that it is based on one of the modern variants of materialism: computational functionalism - a problematic, reductionist cognitive theory.

\section{Keywords}

transhumanism, cyber-immortality, structure of human being, computational functionalism 